\title{
Translanguaging: Implications for the language classroom derived from the revised version of the CEFR
}

\begin{abstract}
One of the basic documents defining, among others, language learning, teaching, and assessment within the EU is the CEFR (2001). Since the moment of its first publication, many political and social changes have occurred which necessitated the reshaping of general language teaching policy to meet the new conditions. There also appeared new theoretical reflections on the process of language learning and language use. Through enhanced mobility a remarkable number of European citizens have become plurilingual, living in multilingual environments. On the other hand, new insights into the process of language learning and teaching accentuated the need for the departure from monolingual approaches in favour of translingual practices (Canagarajah 2013; García \& Li 2014). The objective of this article is to present the implications derived from a translingual instinct ( $\mathrm{Li} 2011$ ) for teaching an additional foreign language to plurilingual students. The author of the article derives his reflections from the theoretical underpinnings of multilingualism, his own research on translanguaging and the revised version of the CEFR (2018).
\end{abstract}

KEYWORDS: translanguaging, linguistic hybridity, ecolinguistics, foreign language learning and teaching, the CEFR.

\section{INTRODUCTION}

In the postmodern era, language has received exceptional attention on the part of academics since in their understanding it is a fundamental factor in creating social reality. This trend has been dubbed as the "discursive turn" in social studies and humanities. No doubt language has a formative power in this regard, the field of Critical Discourse Analysis communicates it in the most direct way. Hence, reflection upon language is essential for the understanding of many social processes. This should be of particular importance for foreign language teachers who, apart from the function of developing language skills, should play "the role of transformative intellectuals who strive not only for academic advancement but also for personal transformation, both for themselves and for their learners" (Kumaravadivelu 2012: 9). For this to be effectuated, a high level of critical language awareness and autonomy is required on the part of the 
teacher (Lankiewicz 2015), not only a high level of language proficiency, which should be taken as a given.

The above consideration is of vital importance in the era of globalization and plurilingualism, when the traditional monolingual, ethno-cultural perception of linguistic diversity, given linguistic research on Second Language Acquisition and multilingualism, seems inappropriate and out of date. A crucial development in these areas is marked respectively by the notion of multi-competence (Cook 1991) and research devoted to translingual practices (Canagarajah 2013; García \& Li 2014), including the idea of translingual instinct (Li 2011). Informed by these concepts, teachers might adjust their beliefs pertaining to language learning and teaching.

Additionally, the revised version of the CEFR (2018), a basic document shaping language policy and language teaching practices with the European Union, delineates new perspectives in this regard. The objective of this article is to present implications for teaching an additional foreign language to plurilingual students. I derive my reflections from the theoretical underpinnings of multilingualism, my own research on translanguaging and I try to demonstrate how translingual practices constitute an integral part of the revised version of the CEFR (2018). More practically, I offer some guidelines for recognizing translingual practices in the classroom.

\section{PLURILINGUALISM AND TRANSLINGUAL PRACTICES}

The political and economic changes in Europe as well as the processes of globalization have resulted in new challenges for language education. Plurilingualism is not only the recommendation of the CEFR $(2001,2018)$ but a fact (cf. Widła 2016). The old paradigm of language teaching, dubbed monolingual, meets neither the inside reality (that of the language classroom), nor the communication conditions of the world at large. In sociolinguistic terms, communities have become multilingual and multicultural, while from the psycholinguistic perspective their citizens have become plurilingual and pluricultural.

Theoretical reflections on plurilingualism recognize the fact that one cannot expect a plurilingual individual to approach the process of language learning and use in the same way as a monolingual person (cf. Cook 1991). In short, the plurilingual mind cannot function in the same way as a monolingual one and for this reason the objectives of language learning cannot be informed by the competence of a native speaker. On the other hand, native language and the whole set of linguistic repertoires has an impact on language learning and communication processes. This influence should not necessarily be perceived in the 
perspective of transfer and interference, but more in the dimension of linguistic creativity and communicational efficiency.

A phenomenon which caught the attention of many language scientists working on multi- and plurilingualism is translanguaging. Above all, this notion embodies a completely new approach to language study, questioning the monolingual fixity and stability of language (for criticism see Harris 1981) in favor of poststructural "mobility, mixing and political dynamics, and historical embedding" (Bloomaert \& Rampton 2011: 3, cited in Mazak 2017: 3). The very notion of language is substituted with languaging, standing for continuity of linguistic resources, or personal and creative use of linguistic repertoires in the process of meaning making. Correspondingly, García and Leiva (2014: 204) posit that "language is an ongoing process that only exists as languaging". Consequently, the notion of translingualism stands for the fact that plurilingual individuals do not have separate systems in their brain for separate languages but rather one underlying faculty to draw upon (García \& Li 2014) and thereby any language exchange between people with a different background produces new meanings and new uses of linguistic repertoires. For Canagarajah (2013: 6) translingual practice means that "communication transcends individual languages" and, in turn, "communication transcends words and involves diverse semiotic resources and ecological affordances". Therefore, it is believed that, in the process of communication, plurilingual individuals draw upon hybrid linguistic repertoires which include "the full range of linguistic performances of multilingual language users" (Li 2011: 1223) "across all modalities of language, from code-switching and mixing to translation and transliteration" (Androutsopoulos 2013).

Drawing on various sources, Mazak (2017) presents different uses of the term translanguaging, which I try to classify slightly differently. It may be perceived as: (1) a pedagogical approach which enhances teaching and "indexes the speakers' shifting multilingual and multicultural identities" (p. 3). In fact, she ascribes the first use of the term to a Welsh bilingual researcher. He used it as a teaching strategy in which "the input (reading and writing) tends to be in one language, and the output (speaking and writing) in the other language, and this is systematically varied (Baker 2006: 297 cited in Mazak 2017: 1). This would stand for the phenomenon of intercomprehension. The term may also be understood as (2) a natural practice of plurilingual people, who are very creative in their performance and use linguistic and other semiotic repertoires in an instinctive way (Li 2011). This category, in my opinion, comprises translanguaging as a theory of bilingualism (compare Mazak 2017: 5). It is also argued that translanguaging may be used as (3) a method or an analytical tool for portraying multifaceted ways plurilinguals "navigate their everyday bilingual worlds" (Mazak 2017: 5). Lastly, translanguaging may be understood as (4) a language ideology, taking 
bilingualism (or possibly plurilingualism) as a norm. Worth pointing out, in Mazak's taxonomy, is the claim that translanguging is of a transformational character (in actuality, she presents this feature as a category). In my opinion, this observation epitomizes the new paradigm in language research on bilingualism or plurilingualism, when she says that it "transforms not only our traditional notion of 'languages', but also the lives of bilinguals themselves as they make the world through language" (Mazak 2015: 5).

\section{THE MEANING OF THE REVISED VERSION OF THE CEFR (2018) FOR FOREIGN LANGUAGE TEACHERS}

The Common European Framework of Reference for Languages (2001) shaped the general policy of language teaching and its evaluation for two decades. It theoretical and methodological underpinnings were basically informed by the communicative approach to language learning and teaching, despite an initial reservation that "[i]t is not the function of the Common European Framework to lay down the objectives that users should pursue or the methods they should employ" (CEFR 2001: notes for the user [no page number]). Yet, this conclusion may be derived from the principles and practices recommended in the document, particularly the accentuation of communication needs in defining learning outcomes. The opinion that the CEFR was shaped by the co-called Communicative Approach to language learning seems to be shared by Komorowska (2017: 166). Another inspiration for the document was the umbrella term of autonomy in language learning, suggesting that the learner should take responsibility for their learning process, including setting objectives, choosing materials and methods, as well as self-evaluation (Holec 1981). Autonomy envisioned the function for language teachers as facilitators of the natural processes of learning through a proper organization of their teaching practices so that our students become better learners and ultimately better citizens by application of the action-oriented approach (CEFR 2001). The desired competences were in the form of knowledge, attitudes and skills "which enable them [learners] to meet the challenges of communication across language and cultural boundaries (i.e. to carry out communicative tasks and activities in various contexts of social life with their conditions and constraints)" (CEFR 2001). Surely, the focal point of eponymous "reference" was to offer parameters and descriptors mapping targeted competences in the form of language levels). Its scales were available for more than 40 languages, including sign language (Figueras 2012: 477).

This document has become the foundation for European and national language education policies regarding textbooks, testing and evaluation at different 
levels of schooling. It has been used as a point of reference of language education also in the Americas and Asia-Pacific (Martyniuk \& Noijons 2007: 7). The document has been both the subject of praise (e.g. North 2000) and harsh critique. The latter pertains to its vagueness of reference descriptors, its impracticality and openness to misuse (e.g. Morrow 2004; Weir 2005; Fulcher 2004; Hulstijn 2007) as well as the criticism of neoliberal accountability in the educational milieu (Boufoy-Bastick 2015). Figueras (2012: 482) aptly groups the CEFR critiques into two main domains: the content area and the political area. It is worth stressing that the perceived limitations of CEFR have resulted in localized, national versions of this document (Alderson 2017).

Envisioned in the 2001 edition of the CEFR, operationalization of language learning and teaching, however influential, catalytic and successful, was surely not without flaws and some of the criticism, as Figueras (2012: 482) puts it "is shared by authors and users alike and will need to be addressed in the future". The document has also been challenged by "recent changes in the social and cultural landscape of Europe" (Komorowska 2017: 165) and new conceptualizations of language learning, underscoring the second language acquisition perspective and breaking with monolingual approaches to plurilingual minds and multilingual or multicultural milieus. Eventually, the Council of Europe published an updated version of the CEFR with a telling subtitle Companion volume with new descriptors (2018).

The new edition of the document has been re-edited, regarding the criticism pertaining to "[i]nsufficient definition, gaps, and terminological incoherences [sic]" as signaled by critics (cf. Figueras 2012: 483). In this respect, the bulk of vague words or terminology have disappeared from the descriptors, which have been validated, completed or broadened. For example, new aspects such as phonology control or individual descriptors appeared. Recommended pedagogy has been supplemented with life-like tasks and "'Can do' descriptors rather than a deficiency perspective focusing on what the learners have not yet acquired" (CEFR 2018: 26). In the move away from the four language skills (the monolingual version of language teaching, cf. Malmkjær 1998), mediation has been added to the modes of communication, together with reception, interaction and production. More importantly, however, for the considerations in the article, the Companion volume with new descriptors (CEFR 2018) redefines basic concepts. Significantly, the notion of language is replaced with languaging. Additionally, it develops the concept of plurilingual and pluricultural competences, which, in the opinion of Komorowska (2017: 172-173), was a weak point of the former version, and she hoped the updated version would be informed (as it finally was) by the document issued by the Council of Europe titled: Guide for the development and implementation of curricula for plurilingual and intercultural education (Beacco 
et al. 2010). The revised version of the CEFR in this regard helps to deconstruct the very notion of what it means to learn a language, and restores the value of all other linguistic systems and their sociocultural backgrounds, including the native one, in the mind of the learner.

In order to avoid misunderstanding, it is important to underscore here that some of the above mentioned terms, like plurilingual and pluricultural competences or mediation, appeared also in the 2001 version of the CEFR, yet they received a new framework or an extended meaning in the application to the process of language learning and teaching. The process of mediation, for example, as the CEFR Companion volume (2018: 32) states, "tended to be reduced to interpretation and translation" while Appendix 5 to this document presents a wider and more conceptual approach to mediation (CEFR 2018: 175). Again, the document points out that the 2014-2017 Project to develop descriptors for mediation was informed by psychological and neurological research evidencing the activation of plurilinguistic means by "both people who learn an additional language early in life and those who learn them later, with stronger integration for the former" (CEFR 2018: 175). Thereby, mediation becomes also a key mode of communication between individuals.

Plurilingual and pluricultural competence is defined as "the ability to call flexibly upon an inter-related, uneven, plurilinguistic repertoire" (CEFR Companion volume 2018: 28). To build a good reference base for my future considerations it is necessary to quote the range of activities it includes:

- switch from one language or dialect (or variety) to another;

- express oneself in one language (or dialect, or variety) and understand a person speaking another;

- call upon the knowledge of a number of languages (or dialects, or varieties) to make sense of a text;

- recognise words from a common international store in a new guise;

- mediate between individuals with no common language (or dialect, or variety), even with only a slight knowledge oneself;

- bring the whole of one's linguistic equipment into play, experimenting with alternative forms of expression;

- exploit paralinguistics (mime, gesture, facial expression, etc.) (the CEFR 2018: 28).

A cursory examination of the above characteristics of what it is to be plurilingual suggests the conclusion that such individuals activate their entire semiotic repertoires and various linguistic and cultural recourses at their disposal in their communication endeavors. This is compatible with the theoretical concept of multi-competence (Cook 1991), questioning the monolingual approach to language learning. It also prevailed in SLA research, promoting stability of inter- 
-language development, aimed at approaching the target language and culture, and basically assuming a one culture, one language paradigm.

An ecological approach to language learning and teaching summarized by van Lier (2010) to three basic concepts (relationships, quality and agency, see also van Lier 2004; Kramsch 2002) as well as research on multilingualism (García \& Li 2014) inform researchers and teachers that this compartmentalized vision does not allow for the majority of processes engaged in the process of language learning and use. The ones which are focal for this article are translingual practices, popularized among applied linguistics by the publication of Canagarajah (2013) and his concept of language meshing, in place of traditional code-switching.

Translanguaging may be simply understood as the side-effect of the process of mediation, which "emphasises the two key notions of co-construction of meaning in interaction and constant movement between the individual and social level in language learning, mainly through its vision of the user / learner as a - holisticocial agent" (the CEFR Companion volume 2018: 33). Plurilingual individuals activate their translingual instinct (Li 2011) to communicate their meanings in multilingual environments. The characteristics of plurilingual and pluricultural competence can be easily construed as accounting for translingual practices, even if the whole revised document of the CEFR Companion volume (2018) does not use the term even once.

Referring to the definition of translingualism mentioned in the earlier section of this paper, it is possible to match types of translingual practices with activities targeting at developing plurilingual and pluricultural competence. In short, the path leads plurilingual individuals across traditional code-switching, intercomprehension, experimentation with altered forms of expression (linguistic hybrids) to trans-semiotizing (using words in a new guise or exploitation of paralinguistics). The comment in the updated version of the CEFR stresses the fact that the concept of plurilingual and pluricultural competence was "developed as a form of dynamic, creative process of 'languaging' across the boundaries of language varieties" (the CEFR 2018: 28) and finds its elaboration in the notion of partial competences (imperfect proficiency of a particular language, which nonetheless enriches general plurilingual competence). Ultimately, I would dare to claim that translingual practices, in the form of linguistic mediation, are recommended in the fundamental document shaping foreign language pedagogy. Hence, translingual practices should somehow be recognized by teachers as a sign of mediation, not as a manifestation of linguistic deficiency, as it normally is.

The problem, however, remains how to accept translingual practices in the basically monolingual class of a foreign language, e.g. English during which plurilingual students of different backgrounds may activate an array of linguistic and cultural repertoires to communicate their meanings. Research on translan- 
guaging in multilingual settings (Muzak \& Carroll 2017) presents examples of effective translingual practices in subject matter education offered to individuals from different linguistic and cultural backgrounds. To my best knowledge, there is little research except my own modest endeavor (Lankiewicz, in press) pertaining to translingualism in a typical foreign language class. This is not to say that the plurilingual approach to foreign language study is not discussed (e.g. Kucharczyk \& Szymankiewicz 2016). Nonetheless, some of the findings, conclusions and suggestions derived from research on translingualism in subject matter education may be applicable to the context of teaching a foreign language.

\section{DEALING WITH TRANSLINGUAL PRACTICES IN AN L2 LANGUAGE CLASSROOM - FROM A TRANSLINGUAL INSTINCT TO A PEDAGOGICAL STANCE}

There is no doubt that both versions of the CEFR promote a plurilingual approach but the updated version makes it more explicit, and the recognition of plurilingual activities represents a milestone in the conceptualization of language learning. Even if the updated document does not mention at any point the existence of translingual practices, they constitute an inherent potential of any plurilingual mind in the form of instinct, as claimed by $\mathrm{Li}$ (2011). Considering the impact of the CEFR on language education policy and syllabus design, translingual practices, evocative of plurilingual and pluricultural competence, will have to be recognized in a language class and dealt with by the teacher.

In Poland, as in many other European countries, school curricula include more than one foreign language. If one adds enhanced mobility and the role of mass media in developing the global village, it is not feasible that an individual learning, e.g. English as a foreign language will assign a section of their brain to store new words, grammar and cultural knowledge, and subsequently use it discriminately when needed. In reality, such minds have never existed. However, the history of language teaching methods seems to be based on a different conviction.

Translingual practice is, and will be, given recent tendencies, more strongly evidenced during foreign language classes. As my research shows (Lankiewicz, in press), it is one thing to develop plurilingualism on the level of the curriculum, it is quite another to deal with code meshing and linguistic hybridity during a classroom dedicated to one language. In the cited research I delve into discursive practices of students learning / using more than one L2 in the educational setting during a typical English as a foreign language classroom. The examination of their narratives and their languaging about language (Swain 
2006) discloses how they position themselves as L2 language users or more precisely as plurilinguals.

Even if most plurilinguals mix language codes during communication, schools basically teach languages as separate entities in a designated place and time (no criticism intended!). This, however, may constitute a challenge for any language teacher, including instructors of mother tongues to native audiences. The influence of English upon Polish, for example, is so strong that during translation classes university students find it difficult to believe that certain expressions which seem natural to them are, in fact, alien to Polish. They are simply popular calques form ubiquitous English which younger generation takes for their native language. Cultural sensitivity and linguistic awareness (characteristics of professional translators) require that they should look for more native equivalents.

A crucial element to be considered in managing language classroom of plurilingual minds are teacher beliefs regarding what language is and what it means to learn a language. In general, teacher beliefs (Pajeres 1992) or, what Kumaravadivelu (2012:32-34) calls, personal knowledge in teacher cognition, are reflected in the pedagogical endeavors of the teacher. This distilled teacher knowledge is mostly the result of their own local experience to judge what works and what does not work. It is very much idiosyncratic, and may be developed in spite of any dominant language teaching theories and practices. Personal knowledge, researchers postulate, "guides them [teachers] in practice of everyday teaching" (Kumaravadivelu 2012: 33) and it also may have an impact on student outcomes (Pajeres 1992: 327). Assuming that the majority of language teachers were educated using the monolingual paradigm, it is highly improbable that they can easily recognize and accept translingual practices among students. Not knowing how to deal with them, they very likely categorize these instances as odd occurrences, inhibiting the process of language learning and interfering negatively with students' language proficiency.

Thereby, a change in teachers' personal beliefs seems to be a vital component in the promotion of plurilingual attitudes to language teaching. Deeply ingrained myths are difficult to dispel, yet some in-service teacher training may have a crucial role in informing in-service teachers about new trends in language study and language teaching polices (e.g. the Council of Europe recommendation regarding the promotion of plurilingual and pluricultural competences). These should offer essential suggestions for classroom activities. As Kumaravadivelu (2012: 33) points out, evoking Clandinin (1992), "teachers construct and reconstruct their personal knowledge as they live out their stories and retell and relive them through a continual process of self-reflection". Thereby, teacher education plays a crucial role in introducing the plurilingual approach to education in general and language teaching in particular. Carroll (2017:183) accentuates this 
element in the promotion of translingual practices among pre-service teachers in formal education.

Related to the above is the claim that potential negative teacher attitudes towards students' translingual practices may result from procedural disorientation of how to deal with them. Related questions recur during my presentations on translingualism during conferences. Teachers seem insecure and confused, and so they should, since even the updated CEFR, presenting the concept of partial competences which plurilingual and pluricultural competence entails, does not dedicate much space to mutual influences between languages, except for presenting illustrative descriptor scales for different languages in reference to language modes. The fact of mutual influence between languages in the plurilingual mind is taken for granted. The task of creating descriptors in this regard seems after all unfeasible. Nevertheless, plurilingual competence pertains to levels of communication within four modes, and it includes linguistic hybridity, affecting the language which is the focus of attention during a particular lesson. Hence, some guidance for the teacher on how to deal with translingual practices seems to be a must.

Evoking the concept of translingualism as a pedagogical stance, which Mazak (2017: 5) defines as drawing on "all of the linguistic and semiotic resources as they [teachers and students] teach and learn both language and content material in classrooms", it is recommended here to use the potential of translingual practices in developing plurilingual competence. Some authors posit here the notion of the didactics of transfer (Kucharczyk \& Szymankiewicz 2016: 65) which allows the transfer of knowledge and skills across languages. They mention two types of transfer: methodological and metalinguistic. While the former pertains to the activation of similar strategies in language learning, the latter refers to linguistic knowledge and language skills. Keeping translingual practices in mind, the teacher should perceive them as a sign of learning - the student making guesses by analogy, or activating their linguistic creativity. In this way, such practices may be perceived as indicative of common underlying plurilingual competence.

It important to mention here that the CEFR is accompanied by other documents and recommendations of the Council of Europe such as A framework for reference for pluralistic approaches to languages and cultures, known as FREPA or (CARAP - French acronym), the result of a project to create a "tool which aims to establish links between languages and language varieties that a learner knows or is learning" (cf. online page: https:/ / carap.ecml.at). Kucharczyk (2017) comments on the feasibility of the teaching practices promoted by the document during a second language class, and foresees great potential for the awakening to language approach, recommending didactic activities which "involve a com- 
parison of languages that are not taught at school, in order to find some similarities and to become accustomed to strange sounds" (Kucharczyk 2017: 174) or intercomprehension of related languages is believed to develop receptive skills. He sees problems with integrated didactics, whose aim is "to help learners to become aware of the relations between the languages taught at school" (Kucharczyk 2017: 174). This is due to the fact that many teachers are not competent enough to make comparisons between many languages, apart from their mother tongue and the language they teach. He proposes, in this regard, the development of "a glottodidactic model based on the learner's language resources, which could be used in formal education, at a foreign language class" (Kucharczyk 2017: 175).

The presentation of the above mentioned model is certainly not within the scope of this modest paper, but below I propose some guidelines derived directly from the definition of plurilingual competence or other sources promoting translingual practices, and adapt them to the context of English as a foreign language.

First of all, it is recommended to move away from the sterility of the English classroom in which a native speaker of some kind is a frame of reference, because the perfect knowledge of a language is no longer the objective of foreign language learning (Kucharczyk \& Szymankiewicz 2016: 67). This goes in line with the idea of partial competences, or uneven proficiency of the plurilingual language learner / user (cf. the CEFR: 36ff). Code-switching and intercomprehension offer good learning opportunities rather than depriving students of communication opportunities, as was elucidated in the strong version of the communicative approach. Language mixing, in this context, may be perceived as a communication strategy, the result of partial competence or, sometimes, a sign of linguistic creativity. Some examples of translingual practices evidenced during my research may be construed as pure language play, where language leaner / users are fully aware of their idiosyncratic character (cf. Lankiewicz 2020).

Subsequently, it is natural for an English classroom to contain voices derived from other languages, be it students' native language or any other linguistic systems that represent their linguistic repertoires. In a sense, linguistic hybridity and translingual practices may stand for the high level of students' critical language awareness and empowerment (cf. Lankiewicz 2020). By resorting to plurilingual competence, students communicate their identity conflicts. Additionally, it needs to be stated that the meaning of any discursive passage is not in the text but in the mind of the writer / reader. Linguistic repertoires allow decoding of texts (e.g. a person knowing some French understands written Italian) or, on the other hand, they enrich them. Some ironic references may occur at the crosswords of languages, these undertones are frequent in lyrics of popular songs when band members come from various countries, e.g. the hip-hop group N-Dubz, who write and sing in Multicultural London English, or the intended hilarious effect 
of the Czech singer Nicky Tučková ${ }^{1}$ performing partly in Polish and partly in Czech. Depending on who the audience is, lyrics may have a totally different meaning. Pop culture embodies young people's translanguaging practices, hence keeping them away from an English class, or by extension from any foreign language class, would be silencing young people's voices. A language class offers a lot of possibilities of incorporating language games, to sensitize students, for example, to false friends. This would be recognizing "words from a common international store in a new guise" while calling upon the plurilinguistic repertoire (the CEFR 2018: 28).

Ultimately, the recommendation for mediating meaning in language learning, postulated by the CEFR, draws, in my opinion, heavily on ecological linguistics, which postulates the importance of the outer layer of linguistic context in the meaning making process. Van Lier (2000: 54), in his concept of the layers of context, proposes a rule that "if an interpretative conflict should arise between two circles [inner - linguistic and outer - interactional and social], the interpretation suggested by the outer circle is likely to prevail over the interpretation suggested by the inner circle". This rule fits perfectly the process of mediation. García's (2009 cited in He, Lai \& Lin 2017: 92) dynamic model of bilingualism highlighting "language practices of different planes, including 'multimodalities' (different modes of language, visuals, sounds and gestures, etc.)" recommends transsemiotizing as a communicative strategy since "languages [...] not only interact with each other but they also intertwine with other semiotics [...] in human communication practices $[\ldots] "$. This, in turn, is compatible with the characteristics of plurilingual competence envisaged in the CEFR (2018).

In practical terms, it means that appreciation of content over form in speaking activities, assuming that real life communication is rarely perfect in form, particularly if interlocutors are emotionally engaged. It should be justly assumed that foreign language learners / users are guided by their affective domain more than first language users. While communicative language teaching was more guided by communication strategies driving at maximum use of the target language (one could say anything as long as it was contained within the semiotic repertoire of that language), plurilingual competence gives priority to meaning. Authenticity and personal voice are the signs of empowerment. Imitation, even if perfect, is seldom taken for autonomy. Prokop's (2002) research pertaining to a typology of didactic interactions in developing personal communicative competence may be very insightful for teacher practitioners who aim at maintaining symmetry, authenticity and conform to felicity conditions in a language classroom.

${ }^{1}$ Even the title of the song "Szukam cię Miłoszu", written in Polish, may be understood in two ways: for Poles (I am looking for you, Miłosz), for Czechs (I am sexing you up, Miłosz). 
The presented guidelines are in no way exhaustive, but they allow the teacher to reflect upon their current practices and possibly revise some deeply ingrained beliefs. Translanguaging is an instinctive behavior of any plurilingual person and it is high time language pedagogy capitalized on it. Whatever the trend of language education policy is, common sense, sensitivity and a basic critical approach and general observation should inform teachers' classroom behavior, rather than well-tried routines. In this vein, Carroll (2017: 183-184) recommends looking beyond the western monolingual norm and "resist the adoption of the marketbased teacher reform that focuses on standardized assessments and increasingly globalized metrics" and, I might add, promote a plurilingual and pluricultural approach among teachers themselves. Taking up learning of an additional language by the teacher would help to adopt a new perspective, that of a learner and a plurilingual user. Nothing is more informative than first-hand experience.

\section{CONCLUSION}

To recapitulate, it is necessary to state that translingual practices are neither alien to a plurilingual mind, nor a rare oddity happening during a foreign language class. They are, in the first place, evocative of a linguistic potential (common plurilingual competence) and the processes linguistic resources are subjected to by a creative user. It is high time teachers understood the basic truth that any linguistic system presents only an affordance (potentiality of form and meaning) and the agency of the user adapts it to their social and psychological contexts in the process of communication. Hence, some modern applied linguistics decided to give priority to the process of languaging in place of the static notion of a language.

It also remains unquestionable that the development of plurilingual and pluricultural competence has become an important point of reference, and no foreign language teacher can remain blindly oriented towards native speaker norms. Teachers should realize that the learner's mother tongue, and any other languages they know, can be effectively drawn upon in the process of language education. The above considerations may be concluded with a comment from a pilot plurilingual approach " $\mathrm{t}$ ] he activities contributed in raising the learners and the teachers awareness regarding the importance of plurlingualism in the learning environment as well as the positive effects of allowing students to translanguage in the classroom (sic)" (Piccardo 2020). Ultimately, it is worth stressing that projects and subsequent documents launched by the Council of Europe as well as research in applied linguistics try to promote plurilingual didactics. It remains to hope that it will soon prevail over a traditional monolingual foreign language classroom. 


\section{REFERENCES}

Alderson, J.C. (2017). Foreword to the Special issue "The Common European Framework of Reference for Languages (CEFR) for English Language Assessment in China". Language Testing in Asia. Lang Test Asia, 7, 20. https:// doi.org/10.1186/s40468-017-0049-9 [access: 21.02.2020].

Androutsopoulos, J. (2013). Networked multilingualism: Some language practices on Facebook and their implications. International Journal of Bilingualism, 19 (2), 185-205.

Baker, C. (2006). Foundations of bilingual education and bilingualism ( $4^{\text {th }}$ edition). Clevedon: Multilingual Matters.

Beacco, J.-C. / Byram, M. / Cavalli, M. / Coste, D. / Egli Cuenat, M. / Goullier, F. / Panthier, J. (2010). Guide for the development and implementation of curricula for plurilingual and intercultural education. Strasbourg: Council of Europe.

Blommaert, J. / Rampton, B. (2011). Language and superdiversity. Diversities, 13 (2), 1-19.

Boufoy-Bastick, B. (2015). Rescuing language education from the neoliberal disaster: Culturometric predictions and analyses of future policy. Policy Futures in Education, 13 (4), 439-467.

Canagarajah, S. (2013). Translingual practice. Global Englishes and cosmopolitan relations. New York: Routledge.

Carroll, K.S. (2017). Concluding remarks: Prestige planning and translanuaging in higher education. In: C.M. Mazak / K.S. Carroll (eds.), Translanguaging in higher education: Beyond monolingual ideologies (pp. 177-185). Bristol: Multilingual Matters.

Clandinin, D.J. (1992). Narrative and story in teacher education. In: T. Russell / H. Mundy (eds.), Teachers and teaching: From classroom to reflection (pp. 124-137). London: Falmer Press.

Cook, V. (1991). The poverty-of-the-stimulus argument and multi-competence. Second Language Research, 7, 103-117.

Council of Europe (2001). Common European framework of reference for languages: Learning, teaching, assessment. Cambridge: CUP. https://rm.coe.int/16802fc1bf [access: 21.02.2020].

Council of Europe (2018). Common European framework of reference for languages: Learning, teaching, assessment. Companion volume with new descriptors. https:/ / rm.coe.int/cefr-companion-volumewith-new-descriptors-2018/1680787989 [access: 21.02.2020].

Figueras, N. (2012). The impact of the CEFR. ELT Journal Volume, 66 (4) Special issue, 477-485. DOI: $10.1093 /$ elt/ccs037.

Fulcher, G. (2004). Deluded by artifices? The Common European framework and harmonization. Language Assessment Quarterly, 1 (4), 253-266.

García, O. (2009). Bilingual education in the 21 ${ }^{\text {st }}$ century: A global perspective. Oxford: Wiley-Blackwell.

García, O. / Leiva, C. (2014). Theorizing and enacting translanguaging for social justice. In: A. Creese / A. Blackledge (eds.), Heteroglossia as practice and pedagogy (pp. 199-216). New York: Springer.

García, O. / Li, W. (2014). Translanguaging: Language, bilingualism and education. New York: Polgrave Macmillan.

Harris, R. (1981). The language myth. London: Duckworth.

He, P. / Lai, H. / Lin, A. (2017). Translangugaing in multimodal mathematics presentation. In: C.M. Mazak / K.S. Carroll (eds.), Translanguaging in higher education: Beyond monolingual ideologies (pp. 91-120). Bristol: Multilingual Matters.

Holec, H. (1981). Autonomy and foreign language learning. Oxford: Pergamon.

Hulstijn, J. (2007). The shaky ground beneath the CEFR: Quantitative and qualitative dimensions of language proficiency. The Modern Language Journal, 91 (4), 663-667.

Komorowska, H. (2017). Europejski system opisu kształcenia językowego - nowe potrzeby i nowe rozwiązania. Konińskie Studia Językowe, 5 (2), 165-183. http:/ / ksj.pwsz.konin.edu.pl. DOI: 10.30438/ksj.2017.5.2.1 [access: 21.02.2020]. 
Kramsch, C. (2002). Introduction. How can we tell the dancer form the dance? In: C. Kramsch (ed.), Language learning and language socialization. Ecological perspectives (pp. 1-30). London and New York: Continuum.

Kucharczyk, R. (2017). United in multilingualism. A few words about the didactics of multilingualism. Lublin Studies in Modern Languages and Literature, 41 (2), 166-183. DOI: 10.17951/ lsmll.2017.41.2.16.

Kucharczyk, R. / Szymankiewicz, K. (2016). Teorie osobiste dotyczące rozwijania kompetencji różnojęzycznej na lekcjach języka obcego - przypadek przyszłych nauczycieli języka francuskiego. Jezzyki Obce w Szkole, 4, 64-70.

Kumaravadivelu, B. (2012). Language teacher education for a global society: A modular model for knowing, analyzing, recognizing, doing and seeing. New York and London: Routledge.

Lankiewicz, H. (2015). Teacher language awareness in the ecological perspective: A collaborative inquiry based on languaging. Gdańsk: Wydawnictwo Uniwersytetu Gdańskiego.

Lankiewicz, H. (in press). Linguistic hybridity and learner identity: Translingual practice among plurilinguals in the educational setting.

Lankiewicz, H. / Wąsikiewicz-Firlej, E. (2019). Theoretical considerations for developing intercultural sensitivity through translation activities: Beyond the monolingual premise in foreign language education. Neofilolog, 52 (2), 313-334.

Li, W. (2011). Moment analysis and translanguaging space: Discursive construction of identities by multilingual Chinese youth in Britain. Journal of Pragmatics, 43 (5), 1222-1235.

Lier van, L. (2000). From input to affordance: Social-interactive learning from an ecological perspective. In: J.P. Lantolf (ed.), Sociocultural theory and second language learning (pp. 245-259). Oxford: Oxford University Press.

Lier van, L. (2004). The ecology and semiotics of language learning: A sociocultural perspective. Boston: Kluwer Academic Publishers.

Lier van, L. (2010). Telling ELT tales out of school. The ecology of language learning: Practice to theory, theory to practice. Procedia Social and Behavioral Sciences, 3, 2-6.

Malmkjær, K. (ed.) (1998). Translation and language teaching: Language teaching and translation. Manchester: St. Jerome Publishing.

Martyniuk, W. / Noijons, J. (2007). The use of the CEFR at national level in the Council of Europe member states. Documents of the Linguistic Forum 2007. Strasbourg: Council of Europe.

Mazak, C.M. (2017). Introduction: Theorizing translanguaging practices in higher education. In: C.M. Mazak / K.S. Carroll (eds.), Translanguaging in higher education: Beyond monolingual ideologies (pp. 1-10). Bristol: Multilingual Matters.

Mazak, C.M. / Carroll, K.S. (eds.) (2017). Translanguaging in higher education: Beyond monolingual ideologies. Bristol: Multilingual Matters.

Morrow, K. (ed.) (2004). Insights from the Common European framework. Oxford: Oxford University Press.

North, B. (2000). The development of a common framework scale of language proficiency. New York: Peter Lang.

Pajeres, M.F. (1992). Teachers' beliefs and educational research: Cleaning up a messy construct. Review of Educational Research, 62, 307-332.

Piccardo, E. (2018). Webinar on the CEFR Companion volume and practical consideration for implementation. Strasbourg, 30 January 2018. https:/ / rm.coe.int/ plurilingual-and-pluriculturalcompetence-piccardo-/1680788b26 [access: 21.02.2020].

Prokop, I. (2002). Typologia interakcji dydaktycznych. In: W. Wilczyńska (ed.), Autonomizacja w dydaktyce języków obcych: Doskonalenie się w komunikacji ustnej (pp. 159-173). Poznań: Wydawnictwo Naukowe UAM. 
Weir, C.J. (2005). Limitations of the Common European framework for developing comparable examinations and tests University of Roehampton. Language Testing, 22 (3), 281-300.

Widła, H. (2016). Zmierzch bilingwizmu i jego skutki. Neofilolog, 47 (1), 9-19.

Received: 21.02.2020; revised: 12.10 .2020

HADRIAN ALEKSANDER LANKIEWICZ

Uniwersytet Gdański

hadrian.lankiewicz@ug.edu.pl

ORCID: 0000-0001-5124-7861 